\title{
Accessibility to tuberculosis treatment: assessment of health service performance
}

\author{
Tiemi Arakawa ${ }^{1}$ \\ Ricardo Alexandre Arcêncio ${ }^{2}$ \\ Beatriz Estuque Scatolin ${ }^{3}$ \\ Lúcia Marina Scatena ${ }^{4}$ \\ Antônio Ruffino-Netto ${ }^{5}$ \\ Tereza Cristina Scatena Villa ${ }^{6}$
}

\begin{abstract}
The aim of this study was to assess the accessibility of patients to the treatment of tuberculosis in Ribeirão Preto, countryside of São Paulo State. Evaluation study type, with a quantity approach. Interviews with 100 patients initiated on anti-tuberculosis chemotherapy between 2006-2007 were conducted, using a structured questionnaire based on the Primary Care Assessment Tool (PCAT). Data were analyzed through variance analysis. There was a positive feedback regarding to organizational accessibility, however, the performance of health services has been unsatisfactory in providing transportation vouchers and in addressing the need to use transport for displacement to the health unit, resulting in indirect costs to patients. The services with the highest number of patients treated were those with higher irregularity in the conduct of home visits, showing that the availability of resources (human, material and time) and the organization of care may influence the accessibility to treatment.
\end{abstract}

Descriptors: Tuberculosis; Directly Observed Therapy; Health Services Evaluation; Health Services Accessibility.

\footnotetext{
${ }^{1}$ RN. E-mail: tiemi.a@gmail.com. Research Development, SP, Brazil. E-mail: ricardo@eerp.usp.br. Development, SP, Brazil. E-mail: scatolin@eerp.usp.br. Nursing Research Development, SP, Brazil. E-mail: tite@eerp.usp.br.

Corresponding Author:

Tereza Cristina Scatena Villa

Universidade de São Paulo. Escola de Enfermagem de Ribeirão Preto

Departamento Materno-Infatil e Saúde Pública

Av. dos Bandeirantes, 3900

Bairro: Monte Alegre

CEP: 14040-902, Ribeirão Preto, SP, Brasil

E-mail: tite@eerp.usp.br
}

2 RN, Ph.D. in Nursing, Professor, Escola de Enfermagem de Ribeirão Preto, Universidade de São Paulo, WHO Collaborating Centre for Nursing

${ }^{3}$ RN, Master's Student, Escola de Enfermagem de Ribeirão Preto, Universidade de São Paulo, WHO Collaborating Centre for Nursing Research

${ }^{4}$ Professor, Departamento de Medicina Social, Universidade Federal do Triângulo Mineiro, MG, Brazil. E-mail: Imscatena@uol.com.br.

${ }^{5}$ Physician, Full Professor, Faculdade de Medicina de Ribeirão Preto, Universidade de São Paulo, SP, Brazil. E-mail: aruffino@fmrp.usp.br.

${ }^{6}$ RN, Ph.D. in Nursing, Full Professor, Escola de Enfermagem de Ribeirão Preto, Universidade de São Paulo, WHO Collaborating Centre for 


\section{Acessibilidade ao tratamento de tuberculose: avaliação de desempenho de serviços de saúde}

O objetivo deste estudo foi analisar a acessibilidade dos pacientes ao tratamento de tuberculose (TB) em Ribeirão Preto, cidade do interior paulista. Trata-se de estudo de avaliação de serviços de saúde, de abordagem quantitativa. Foram entrevistados 100 pacientes que iniciaram o tratamento de TB entre 2006-2007, utilizando questionário estruturado, baseado no Primary Care Assessment Tool (PCAT). Os dados foram submetidos à análise de variância. Observaram-se avaliações positivas em relação à acessibilidade organizacional, porém, o desempenho dos serviços de saúde foi pouco satisfatório no oferecimento de vale-transporte e na necessidade da utilização de transporte no deslocamento até à unidade de saúde, gerando custos indiretos aos pacientes. Os serviços com maior número de doentes atendidos foram aqueles que apresentavam maior irregularidade na realização de visitas domiciliares, demonstrando que a disponibilidade de recursos (humanos, materiais e tempo) e a organização da atenção podem influenciar na acessibilidade ao tratamento.

Descritores: Tuberculose; Terapia Diretamente Observada; Avaliação de Serviços de Saúde; Acessibilidade aos Serviços de Saúde.

\section{Accesibilidad al tratamiento de tuberculosis: evaluación de desempeño de servicios de salud}

El objetivo de este estudio fue analizar la accesibilidad de los pacientes al tratamiento de tuberculosis (TB) en Ribeirao Preto, ciudad del interior del estado de Sao Paulo. Se trata de un estudio de evaluación de servicios de salud, con abordaje cuantitativo. Fueron entrevistados 100 pacientes que iniciaron el tratamiento de TB entre 20062007, utilizando un cuestionario estructurado basado en el Primary Care Assessment Tool (PCAT). Los datos fueron sometidos al análisis de varianza. Fueron observadas evaluaciones positivas en relación a la accesibilidad organizacional, sin embargo, el desempeño de los servicios de salud fue poco satisfactorio en el ofrecimiento de ayuda de dislocamiento y en la necesidad de la utilización de transporte en el traslado hasta la unidad de salud, generando costos indirectos a los pacientes. Los servicios con mayor número de enfermos atendidos fueron los que presentaban mayor irregularidad en la realización de visitas domiciliares, demostrando que la disponibilidad de recursos (humanos, materiales y tiempo) y la organización de la atención pueden influir en la accesibilidad al tratamiento.

Descriptores: Tuberculosis; Terapia por Observación Directa; Evaluación de Servicios de Salud; Accesibilidad a los Servicios de Salud.

\section{Introduction}

The World Health Organization (WHO) emphasizes the importance of the organizational and health service performance dimension in tuberculosis (TB) control actions, stating that the problem is not in the forms of detection and treatment, but rather in the way health services are organized to detect and treat TB cases $^{(1)}$. The DOTS (Directly Observed Therapy, Short-Course) strategy, currently expanded by the STOP TB plan, emphasizes this idea, as it constitutes a TB control policy included in the health system instead of a simple protocol with a clinical approach(2).

TB care also implies dealing with a disease considered to be a chronic condition, requiring specific abilities to provide a unique service, as this is a long- 
term disease ${ }^{(3)}$. It is known that lack of adherence to TB treatment, which lasts at least six months, represents one of the most challenging aspects to control this disease, because it leads to an increase in mortality, incidence and multidrug-resistance ratios $^{(4)}$.

National and international studies show that obtaining therapeutic success goes beyond pharmacological efficacy, involving obstacles to the continuity of health care during TB treatment, associated with factors intrinsic to both treatment and patient and with the way the service is organized for health care delivery ${ }^{(5-6)}$. In addition, there is the fact that treatment adherence goes beyond the approach that reduces an individual's health needs to the clinical and biological aspects, as TB is directly associated with and influenced by the social structure patients experience(7).

Accessibility is an important aspect that explains variations in health service use and represents a relevant dimension in health service performance and care quality assessment research(8). Factors predisposing to health service use or not affect an individual's health outcomes, and studying these factors enhances the selection of strategies to adapt health services to population requirements and health care demands(9). Accessibility differs from the concept of access in terms of the nature or quality of what is accessible, and it is defined as "entry, the act of entering"(10). The concept of accessibility is broader than the concept of access, going beyond the entry to services, because accessibility is not restricted to the mere availability of resources at a certain moment/place or the exclusive use of health services or not, although it also indicates the level of adjustment between patient requirements and the services used(11).

In this perspective, it is essential to know how users evaluate the service they receive in order to rethink and intervene in the way services are organized, aiming at higher quality of care, because "any definition of a health care system must consider the dimensions of accessibility, so that theoretical advances related to sector organization can become practices in the services"(9).

The present study aimed to evaluate patient accessibility to TB treatment in different referral services in Ribeirão Preto, an interior city in São Paulo state.

\section{Methods}

This quantitative assessment study was part of a multicenter project developed by the Operational Research Area of the Rede Brasileira de Pesquisa em Tuberculose/REDE-TB (Brazilian Tuberculosis Research Network), conducted in five priority cities for TB control in the Southeast and Northeast. According to the theoretical framework used, the dimension of accessibility was categorized into organizational accessibility, economic accessibility and geographical accessibility $^{(11)}$. Based on these categories, the following indicators were constructed (Figure 1).

\begin{tabular}{|c|c|c|}
\hline \multicolumn{2}{|r|}{ Category } & Indicators \\
\hline \multirow{7}{*}{ Organizational accessibility } & \multirow{7}{*}{$\begin{array}{l}\text { Represented by the obstacles that originate } \\
\text { in the ways health services are organized, } \\
\text { such as delays in obtaining a consultation } \\
\text { and difficulties in setting up consultations. The } \\
\text { guarantee of care continuity is also included in } \\
\text { this dimension. }\end{array}$} & Medical consultation in less than 24 hours \\
\hline & & Lack of medication during treatment \\
\hline & & $\begin{array}{l}\text { Mean waiting time for a follow-up medical consultation longer than } \\
60 \text { minutes }\end{array}$ \\
\hline & & Ease to set up medical consultations for TB control \\
\hline & & Home visit made during treatment \\
\hline & & Public transport tickets provided \\
\hline & & Basic food pack provided \\
\hline \multirow[t]{2}{*}{ Economic accessibility } & \multirow{2}{*}{$\begin{array}{l}\text { Includes consumption of time, energy and } \\
\text { financial resources to obtain health care; losses } \\
\text { due to working days missed; treatment costs. }\end{array}$} & $\begin{array}{l}\text { Working days or appointments missed due to medical } \\
\text { consultations for TB }\end{array}$ \\
\hline & & Transportation expenses to arrive at health service \\
\hline \multirow[t]{2}{*}{ Geographical accessibility } & \multirow{2}{*}{$\begin{array}{l}\text { Related to the mean distance between the } \\
\text { population and health services and to the } \\
\text { reasons for individuals to seek a certain health } \\
\text { service, in a certain location. }\end{array}$} & $\begin{array}{l}\text { TB treatment conducted in the health service closest to the } \\
\text { patient's home }\end{array}$ \\
\hline & & Use of motorized transportation to arrive at the health service \\
\hline
\end{tabular}

Figure 1 - Indicators constructed for this study.

This study was conducted in Ribeirão Preto, a large interior city located in the West of São Paulo state. In this city, health care for individuals with TB is provided by specialized teams of the Programa Municipal de Controle da TB (PCT - Municipal TB Control Program), working in referral services (primary health units, district health 
units and referral centers) situated in each of the five existing health districts.

In total, four referral services (identified as $A, B, C$ and $D$ ) participated in the study. A population census of individuals with TB undergoing treatment in the city was previously conducted, resulting in 167 cases. Patients with TB who were part of the city's prison population, non-residents of the city studied and those younger than 18 years were excluded. As a result, 100 individuals undergoing treatment in the city's referral services, between 2006 and 2007, participated in the study.

Interviews were conducted with individuals using a semi-structured questionnaire, based on instruments included in the Primary Care Assessment Tool (PCAT), validated in Brazil(12) and adapted to tuberculosis control actions $^{(13)}$. This instrument contains questions about each key dimension of Primary Health Care (gateway, access, bond, coordination, family focus, range of services and professional qualification). Questions allocated in the "access" and "service team" dimensions were considered to analyze treatment accessibility.

Each question of the questionnaire was responded according to a Likert scale of pre-established possibilities, in which values from 1 to 5 represented the level of preference or agreement with statements. The indicators constructed for each question corresponded to a mean score, obtained by adding up all interviewed patients' answers, divided by the total number of respondents. The performance of each indicator was classified as follows: mean values around 1 and 2 - unsatisfactory performance; values close to 3 - average performance; and values around 4 and 5 - satisfactory performance. Indicators were subsequently analyzed individually and compared among the four health services. Data were submitted to variance analysis (one-way ANOVA) to evaluate treatment accessibility in referral services. The assumption of equality of variance (homoscedasticity), required by ANOVA, was verified with Bartlett's test. Variance analysis was thus applied to the variables that met the premises of independence, homoscedasticity and normality. The non-parametric Kruskal-Wallis test was applied to those variables that did not meet the criteria for ANOVA use.

In all tests, statistical significance was set at $5 \%$. In compliance with resolution 196/96, approval for this research project was obtained from the Institutional Review Board at the Ribeirão Preto College of Nursing (Protocol 0762/2007) and the project was registered in SISNEP/ CONEP - Conselho Nacional de Ética em Pesquisa (National Research Ethics Council).

\section{Results}

Table 1 - Means and confidence intervals of organizational, economic and geographical accessibility indicators of TB patients per health service and in the city (2006-2007)

\begin{tabular}{|c|c|c|c|c|c|c|}
\hline \multirow{2}{*}{ Variable } & $\begin{array}{c}\text { Service A } \\
n=39\end{array}$ & $\begin{array}{c}\text { Service } B \\
n=24\end{array}$ & $\begin{array}{c}\text { Service C } \\
n=22\end{array}$ & $\begin{array}{c}\text { Service D } \\
n=15\end{array}$ & \multirow{2}{*}{$\begin{array}{c}\text { Mean } \\
\text { Total }\end{array}$} & \multirow{2}{*}{$\begin{array}{l}\text { F test or } \\
\mathrm{H} \text { test }\end{array}$} \\
\hline & $\bar{x} \quad$ s & $\bar{x}$ & $\bar{x}$ & $\bar{x}$ & & \\
\hline $\begin{array}{l}\text { Ease to set up medical consultations for } \\
\text { tuberculosis control }\end{array}$ & $4.94 \pm 0.32$ & $4.87 \pm 0.61$ & $5.00 \pm 0.00$ & $4.86 \pm 0.51$ & 4.93 & 0.6828 \\
\hline Lack of medication during treatment ${ }^{\dagger}$ & $4.61 \pm 0.90$ & $4.87 \pm 0.44$ & $5.00 \pm 0.00$ & $5.00 \pm 0.00$ & 4.82 & 0.0571 \\
\hline Medical consultation in less than 24 hours $^{\ddagger}$ & $4.87 \pm 0.57$ & $4.70 \pm 1.08$ & $4.81 \pm 0.66$ & $3.33 \pm 2.43$ & 4.59 & $0.0148^{*}$ \\
\hline Basic food pack provided $^{\dagger}$ & $3.97 \pm 1.76$ & $4.33 \pm 1.52$ & $4.04 \pm 0.61$ & $4.46 \pm 1.40$ & 4.15 & 0.7030 \\
\hline $\begin{array}{l}\text { Mean waiting time for a medical consultation } \\
\text { longer than } 60 \text { minutes }^{\dagger}\end{array}$ & $3.89 \pm 1.53$ & $4.04 \pm 1.19$ & $4.36 \pm 1.17$ & $4.60 \pm 0.82$ & 4.14 & 0.2629 \\
\hline Home visit made during treatment $^{\dagger}$ & $3.28 \pm 1.41$ & $3.37 \pm 1.66$ & $4.68 \pm 0.71$ & $4.86 \pm 0.51$ & 3.85 & $0.0001^{*}$ \\
\hline $\begin{array}{l}\text { Working days or appointments missed due } \\
\text { to medical consultation for } \mathrm{TB}^{\dagger}\end{array}$ & $3.25 \pm 1.90$ & $4.25 \pm 1.53$ & $3.40 \pm 1.86$ & $3.13 \pm 1.76$ & 3.51 & 0.1407 \\
\hline $\begin{array}{l}\text { Transport expenses to arrive at health } \\
\text { service }^{\dagger}\end{array}$ & $2.61 \pm 1.94$ & $3.50 \pm 1.97$ & $4.36 \pm 1.43$ & $3.40 \pm 1.76$ & 3.33 & $0.0058^{*}$ \\
\hline $\begin{array}{l}\text { TB treatment conducted in the health service } \\
\text { closest to patient's home }{ }^{\dagger}\end{array}$ & $3.33 \pm 1.97$ & $2.33 \pm 1.92$ & $3.36 \pm 2.01$ & $4.20 \pm 1.65$ & 3.23 & $0.0317^{*}$ \\
\hline Public transport tickets provided ${ }^{\dagger}$ & $1.82 \pm 1.57$ & $2.41 \pm 1.90$ & $3.36 \pm 2.01$ & $3.20 \pm 1.93$ & 2.51 & $0.0072^{*}$ \\
\hline $\begin{array}{l}\text { Use of motorized transportation to arrive at } \\
\text { health service }\end{array}$ & $1.56 \pm 1.37$ & $2.00 \pm 1.76$ & $2.54 \pm 1.94$ & $1.86 \pm 1.55$ & 1.93 & 0.1698 \\
\hline
\end{tabular}

$* P$ values $<0.05$

${ }^{+}$Parametric ANOVA (F test)

${ }^{\ddagger}$ Non-parametric Kruskal-Wallis test (H test) 
In the results described above, it could be observed that the services in this study behaved similarly in terms of the following indicators: "ease to set up medical consultations for TB control" and "medications provided during treatment" (which patients rated as satisfactory); "basic food pack provided", "mean waiting time for a medical consultation longer than 60 minutes" and "working day missed due to medical consultation" (rated as average); and "use of motorized transportation to arrive at the health service" (rated as unsatisfactory).

With regard to the distance between the referral service and the patient's home, there was a statistically significant difference in the behavior of services (Figure 2). By applying the comparison of means test (Tukey's test), it could be observed that service B obtained the lowest scores when compared to service $D$, which obtained the best performance. Service B covers the largest area, serving a total of 136,906 inhabitants.

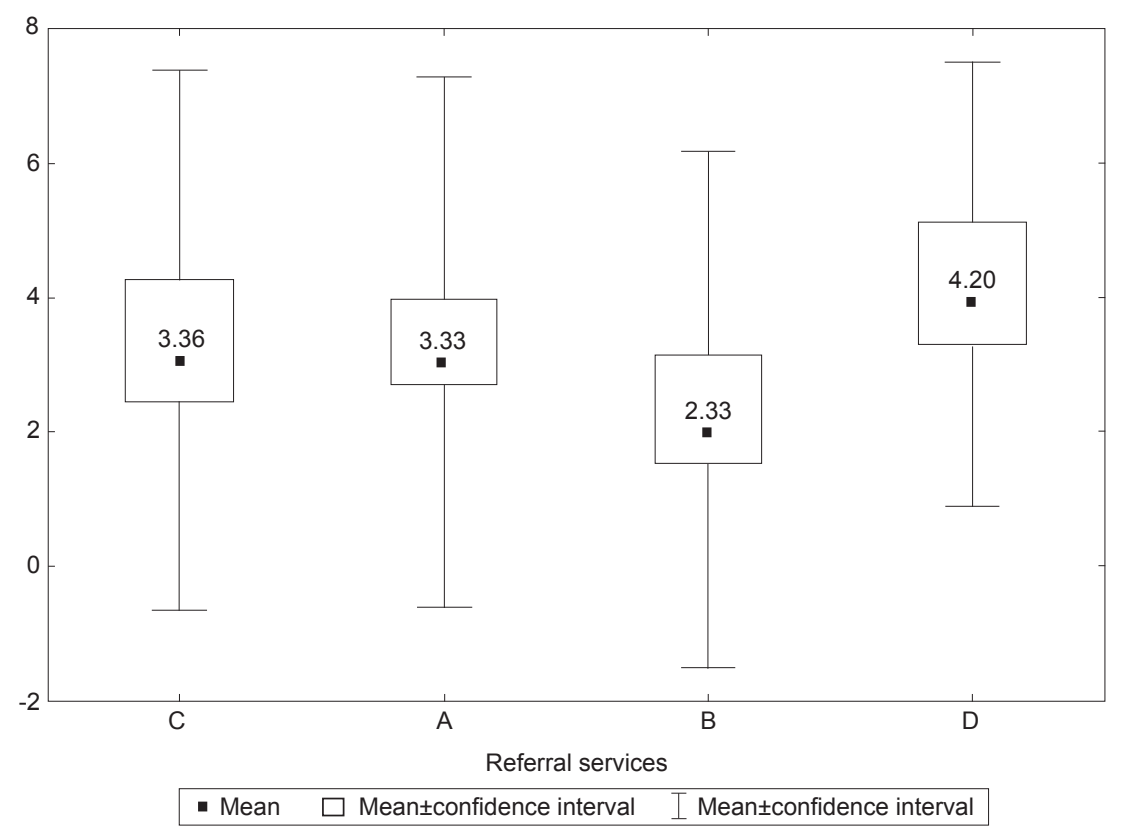

Figure 2 - Mean, confidence interval and standard deviation for the "TB treatment conducted in the health service closest to patient's home" indicator, 2006-2007

With regard to public transport tickets, which showed an unsatisfactory performance in this city, there was a statistically significant difference in the behavior of the four services studied, and Tukey's test showed that services $A$ and $B$ provided this benefit more frequently. In total, $77 \%$ of patients from service $A$ and $62.5 \%$ from service $B$ reported that the service never provided this type of benefit. In addition, services $A$ and $B$ showed the worst performances when compared to services $C$ and $D$, in terms of "transportation expenses to arrive at the health service". 


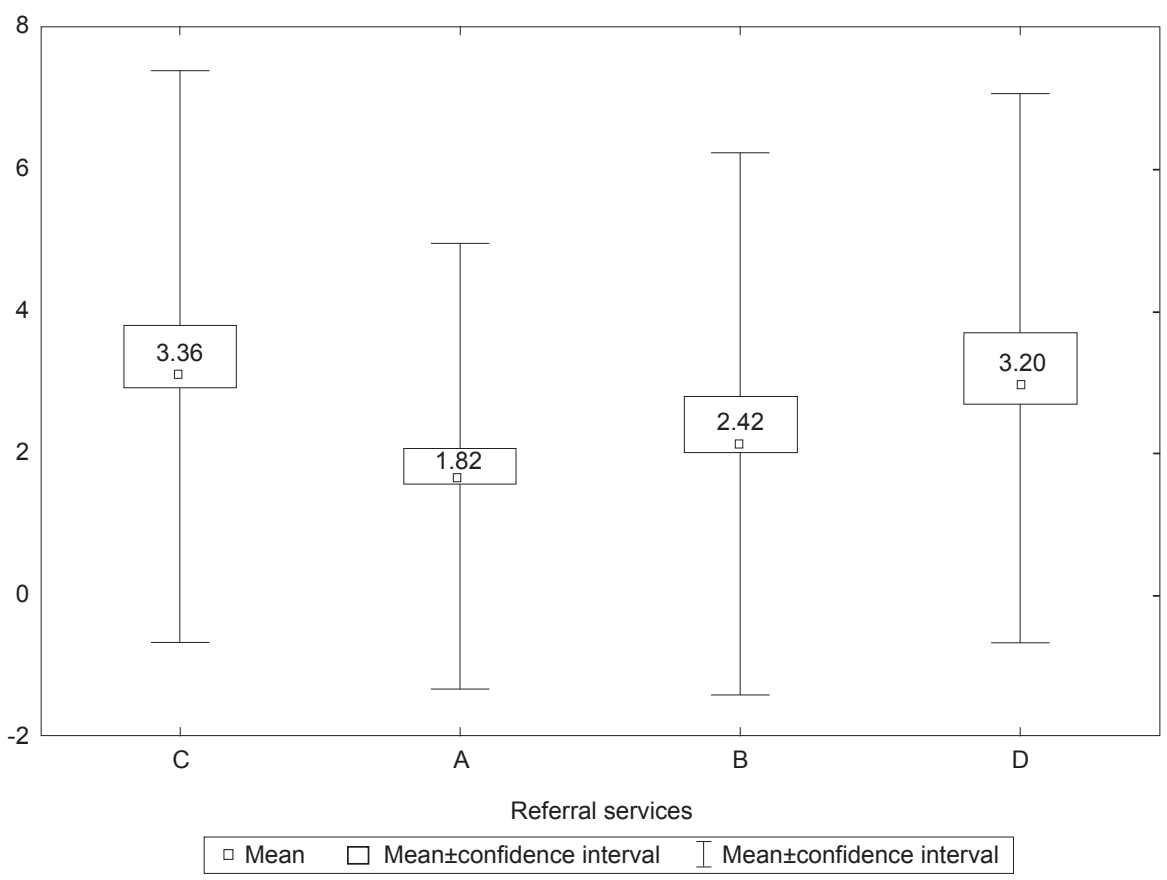

Figure 3 - Mean, confidence interval and standard deviation for the "home visit made during treatment" indicator, 2006-2007

With regard to home visits (HV) made to patients during treatment, services $C$ and $D$ also obtained a satisfactory performance, where $82 \%$ and $93 \%$ of patients received $\mathrm{HV}$, respectively. In contrast, an unsatisfactory performance was observed in services A and $B$, where $28 \%$ and $25 \%$ of participants reported having never received $\mathrm{HV}$, respectively.



Figure 4 - Mean, confidence interval and standard deviation for the "home visit made during treatment" indicator, 2006-2007 


\section{Discussion}

When a health problem requires a service, the health system should be organized in a way that guarantees care is provided from the beginning and that this care is continuous and capable of meeting the needs of individuals who are seeking $i^{(14)}$. Readiness to provide medical consultations, whether these are control (monthly) or emergency consultations (until 24 hours), can indicate that referral services maintain regular control consultations, guaranteeing follow-up of TB treatment progress, in addition to assuring readiness in other possible situations, enabling an individual in need to receive care. The onset of adverse reactions to drugs is a common situation affecting patients who are beginning their treatment, a fact that implies special care and attention from the responsible health team. The waiting time for a medical consultation, rated as satisfactory in this study, also represents an aspect that promotes continuing care, because closeness of the doctor-patient relationship and a more organized service reduce this time ${ }^{(15)}$.

Delays in the service and hours that are incompatible with the patient's work shifts can lead to the patient's need to miss a working day. The literature emphasizes that the rigidity in the routine care of health services aggravates TB patients' economic and social difficulties(16-17). Tuberculosis treatment puts a significant financial burden on patients, many of whom do not have the conditions to afford additional expenses, as they are responsible for the household income ${ }^{(18)}$. When the influence of socioeconomic factors on adherence to TB treatment is recognized, the lack of benefits or support to cover transportation, housing and food expenses can hinder the continuity of treatment, even when treatment is cost-free ${ }^{(19)}$. Providing support, such as public transport tickets and basic food packs, requires that health services be integrated with other social service practices and exemplifies the interrelation between economic and organizational accessibility(20-21).

The fact that treatment of individuals with TB is performed in a centralized way in referral services can explain most organizational accessibility indicators' positive performance. The PCT implemented in the health services has its own specialized team, which works on an outpatient care basis, with specific days and/or times for TB care. After patients join the PCT and begin their treatment, this team directly provides care, thus helping with the sett-up of consultations and the service flow in the context of health services.
However, concentrating care on treatment at referral units can also entail obstacles, related to the distance between the patient's home and the health service where treatment is delivered, hindering geographical accessibility. Nonetheless, it should be considered that only the distance to the health service may not be a relevant barrier, as certain individuals prefer health services situated further away from their home, due to the stigma associated with this disease(22). In spite of this, this distance involves certain aspects, such as the need to use motorized transportation to arrive at the health service and the resulting loss of time, energy and money, which can create several obstacles. The unsatisfactory or average performance of indicators like "use of motorized transportation to arrive at the health service", "transportation expenses to arrive at the health service" and "TB treatment conducted in the health service closest to patient's home" evidences a gap in the accessibility of TB patients undergoing treatment, which ends up causing health care deficiencies.

The results obtained from the HVs reveal this deficiency, where referral services attending a higher number of patients performed worst in terms of HVs. When health services have an extensive area of coverage, home visits become irregular. These results are similar to those of other studies on health services' supervised treatment performance ${ }^{(23-24)}$. Professionals working for health services that concentrate a great number of TB patients and have a larger area of coverage reported greater difficulty to perform the DOTS strategy at home, due to their responsibility to supervise a large number of patients and to the need to go to these homes in a short space of time(23).

Home visits require health services to reorganize their internal activities and to have a minimum structure (vehicle, driver and supervising health professional), which are necessary for the development of TB treatment activities at the patient's home, at the same time as the continuity of activities conducted at the service is guaranteed $^{(25)}$.

TB health care, including home visit planning, should consider patients' needs and preferences and the context they live in ${ }^{(25)}$. In addition to the objective of supervising drug intake, the fact should be emphasized that home visits and direct observation of therapy comprise other aspects, such as the evaluation of contacts and psychosocial support, which are essential for treatment adherence and disease prevention in the family context.

However, performing according to a logic that prioritizes patient-centered care, considering their 
peculiarities and autonomy in view of the therapeutic process, can become a difficult task for health services, with a demand that surpasses their resources and structure.

A single professional's direct observation of patients may be a type of intervention that only deals with the access problem from the health service's perspective. Interventions in the context of organizational barriers, which are limited to solving mechanical problems, do not focus on the service's commitment to and responsibility for user autonomy and rights in the end.

Thus, TB control actions with a focus on the broad concept of health requires that health system and service management takes into account the combination of integrated and specialized activities, with a view to guaranteeing a care model that considers TB's debilitating nature. Good performance of health services in terms of accessibility to treatment depends on a set of conditions, including continuous professional qualification, guarantee of a minimum structure for teams to perform and integration of efforts among different participants responsible for TB control(24), aiming at the optimization and adequacy of existing resources for the several needs of TB patients.

To provide access to and care for all is a challenge that is part of the new public health and primary health care paradigm. In the end, this task meets the specific needs of TB actions, as diagnosis and efficient patient treatment are the primary basis for disease control.

\section{Conclusions}

Health services participating in patient treatment follow-up, organized centrally and relying on specialized teams, performed satisfactorily in relation to most organizational accessibility indices. However, the present study identified the existence of deficiencies in the management of indirect costs imposed on TB patients, such as transportation expenses to the health service and insufficient availability of social support actions (such as public transport tickets and basic food packs). Unsatisfactory performance in terms of the distance between the unit performing direct observation of therapy and the patient's home and irregularity in the availability of home visits to supervise treatment could be associated with operational difficulties in the organization of health care and team resources (human, material and time).

The results emphasize the need for assessment studies to redirect TB care practices, supporting the development process of new strategies to identify obstacles to patient care continuity.

\section{References}

1. World Health Organization. Tuberculosis control: surveillance, planning, financing: WHO Report 1999. Geneva: World Health Organization; 1999.

2. Ogden J, Walt G, Lush L. The politics of 'branding' in policy transfer: the case of DOTS for tuberculosis control. Soc Sci Med. 2003;57(1):179-88.

3. Organização Mundial da Saúde. Cuidados inovadores para condições crônicas: componentes estruturais de ação: relatório mundial. Brasília: Organização Mundial de Saúde; 2002. 105 p.

4. Volmink J, Garner P. Directly observed therapy for treating tuberculosis. Cochrane Database Syst Rev. 2003; (1):CD003343.

5. Munro S, Lewin S, Smith $H$, Engel $M$, Fretheim $A$, Volmink J. Patient adherence to tuberculosis treatment: a systematic review of qualitative research. PLoS Med. 2007; 4(7):1230-45.

6. Villa TCS, Brunello MEF, Arcêncio RA, Sassaki CM, Assis EG, Cardozo-Gonzalez RI. Fatores preditivos aos resultados desfavoráveis no tratamento da tuberculose: revisão integrativa da literatura (2001-2005). Online Braz J Nurs: [periódico na Internet]. jan 2008 ;(7). Disponível em: http://www.uff.br/objnursing/index. php/nursing/article/view/j.1676-4285.2008.1098/288.

7. Terra MF, Bertolozzi MR. O tratamento diretamente supervisionado (DOTS) contribui para a adesão ao tratamento da tuberculose?. Rev. Latino-Am. Enfermagem. 2008;16(4):659-64.

8. Donabedian A. The effectiveness of quality assurance. Int J Qual H. Care. 1996;8:401- 7.

9. Hortale VA, Pedroza M, Rosa MLG. Operacionalizando as categorias acesso e descentralização na análise de sistemas de saúde. Cad Saúde Pública. 2000;16(1):231-9.

10. Travassos C, Martins M. A review of concepts in health services access and utilization. Cad Saúde Pública. 2004;20(2):190-8.

11. Fekete MC. Estudo da Acessibilidade na Avaliação dos Serviços de Saúde. In: Santana JP, Santos I, Fekete MC, Galvão EA, Mandelli MJ, Penna MLF, et al., organizadores. Desenvolvimento Gerencial de Unidades Básicas do Sistema Único de Saúde (SUS). Brasília (DF): OPS; 1997. p. 177-84.

12. Macinko J, Almeida C, Oliveira E, Sá P. Organization and delivery of primary health care services in Petrópolis, Brazil. Int J Health Plann Manage. 2004;19:303-17. 
13. Villa TCS, Ruffino-Netto A. Questionário para avaliação de desempenho de serviços de atenção básica no controle da tuberculose no Brasil. J Bras Pneumol. 2009;35(6):610-2.

14. Starfield B. Atenção primária: equilíbrio entre necessidades de saúde, serviços e tecnologia. Brasília: Organização das Nações Unidas para a Educação, a Ciência e a Cultura/Ministério da Saúde; 2002. 725 p. 15. Lima MB, Mello DA, Morais APP, Silva WC. Estudo de casos sobre abandono de tratamento da tuberculose: avaliação do atendimento, percepção e conhecimentos sobre a doença na perspectiva dos clientes (Fortaleza, Ceará, Brasil). Cad Saúde Pública. 2001; 17(4):877-85. 16. Dimitrova B, Balabanova D, Atun RA, Levicheva $\mathrm{V}$, Coker RJ. Health service providers perceptions of barriers to tuberculosis care in Russia. Health Policy Plan. 2006;21:265-74. 17. Jaiswal A, Singh V, Ogden J et al. Adherence to tuberculosis treatment: lessons from the urban setting of Delhi, India. Trop Med Int Health. 2003;8:625-33.

18. Ogden J, Rangan S, Uplekar M, Porter J, Brugha $R, Z w i$, et al. Shifting the paradigm in tuberculosis control: Illustrations from India. Int J Tuberc Lung Dis. 1999;3(10):855-61.

19. Ramos DD, Lima MADS. Acesso e acolhimento aos usuários em uma unidade de saúde de Porto Alegre, Rio Grande do Sul, Brasil. Cad Saúde Pública. 2003;19:2734.

20. Sagbakken M, Frich JC, Bjune G. Barriers and enablers in the management of tuberculosis treatment in Addis Ababa, Ethiopia: a qualitative study. BMC Public Health. 2008; 8:11.

21. Khan, JD Walley, SN Witter, SK Shah and S Javeed Tuberculosis patient adherence to direct observation: results of a social study in Pakistan. Health Pol Plann. 2005;20(6):354-65.

22. Paixão LMM, Gontijo ED. Perfil de casos de tuberculose notificados e fatores associados ao abandono, Belo Horizonte, MG. Rev Saúde Publica. 2007;41(2):205-13. 23. Gonzales RIC, Monroe AA, Assis EG, Palha PF, Villa TCS, Ruffino-Netto A. Desempenho de serviços de saúde no tratamento diretamente observado no domicílio para controle da tuberculose. Rev Esc Enferm USP. 2008;42(4):628-34.

24. Cardozo Gonzáles RI, Monroe AA, Arcêncio RA, Oliveira MF, Ruffino-Netto A, Villa TCS. Performance indicators of DOT at home for tuberculosis control in a large city, SP, Brazil. Rev. Latino-Am. Enfermagem. 2008;16(1):95-100.
25. Vendramini SHF, Monroe A, Villa TCS. Tratamento supervisionado no controle da tuberculose em uma unidade de saúde de Ribeirão Preto: a percepção do doente. Bol Pneumol Sanit. 2002;10(1):5-12.
Received: Feb. $11^{\text {th }} 2010$

Accepted: Jan. 26th 2011 